\title{
Stone Artefacts from Late Roman Occupation Phases in Nea Paphos
}

\author{
Karolina Pawlik
}

\begin{abstract}
Nea Paphos was a vibrant city in Roman Cyprus. Much information about the history and the inhabitants of the urban centre came to light through extensive excavations, which started at the site in the 1960s. The Hellenistic and Roman period has been widely studied and examined, but our knowledge of late Roman Paphos still remains quite modest. The purpose of this paper is to provide a better understanding of the late Roman phases of occupation, especially of the squatters' activities in Paphos, through the analysis of stone objects, mainly grinding and milling stones and other worked stone, which are associated with this period.
\end{abstract}

Keywords: late Roman Cyprus, Nea Paphos, stone objects, millstones, grinding stones, spolia

Karolina Pawlik, independent researcher, Warszawa; karolinapawlik88@hotmail.com

Nea Paphos is a well-known Roman city on the western coast of Cyprus, on the boundaries of the modern city of Kato Paphos. During the Ptolemaic period the city became an important political and economic centre, finally taking over as the capital of the island. In 58 BC Cyprus became a Roman province and Nea Paphos continued to prosper until the late Roman period. A series of earthquakes in the fourth century AD destroyed large parts of the city, ${ }^{1}$ which was later ( sixth-seventh century) reoccupied and reused for small scale industrial purposes. Nea Paphos has been excavated by teams from various countries: Cyprus, Poland, Great Britain, Italy, France and Australia. ${ }^{2}$ The Polish mission from the University of Warsaw celebrated 50 years of excavations in Paphos in 2015. Research at the site has also been carried out by Polish archaeologists from the Jagiellonian University, who in 2011 started the Paphos Agora Project. The results of their work and that of their foreign colleagues have widely contributed to our understanding of the living conditions in the city of Nea Paphos. Nevertheless, our knowledge of some aspects of life in this urban

\footnotetext{
1 Lichocka, Meyza 2001: 146.

2 DepAntiquitesCyprus.
} 
centre still remains insufficient. One such theme are stone implements associated with the so-called squatter phase (of occupation), dated to the late Roman period. ${ }^{3}$

The analysed material consists of thirty portable and non-portable stone finds. They represent the following categories: grinding stones, querns and millstones, storage vessels, elements of press weight, other rural installations and spolia. The majority of these objects can be characterised as non-portable objects.

The terminology used by archaeologists to describe stone implements is sometimes quite imprecise, which can make identification and comparisons difficult. In this article, when applicable, the author intends to use the terminology presented by Katherine Wright. ${ }^{4}$ By terminology the author means the terms used to name different part of vessels and not the typology itself. There are a few known stone objects typologies ${ }^{5}$ but these address objects used in the Bronze Age and in other regions of the Mediterranean, Crete and the Levant among others. Using a typology created for a different historical period does not seem entirely methodologically correct, when one considers the technological innovations introduced by the Romans. Katherine Wright's terminology, on the other hand, is appealing because it is well-defined, clear and based on morphological attributes. When appropriate, the author will also use the typology for querns and millstones proposed by David Peacock. ${ }^{6}$

The analysed finds from Nea Paphos are usually made of a locally available material - calcarenite, although some are made of other types of limestone, basalt and there are a few marble objects. The identification of the rock type is based entirely on visual observation and a brief consultation with a geologist. ${ }^{7}$ Unfortunately, at the time of writing this article, little archaeometric or petrographic analysis of stone material from the site has been conducted. Preliminary geological studies, focusing on building and decorative stone material have been carried out by Michalina Dzwoniarek-Konieczna. ${ }^{8}$ According to her research, the local calcarenite has been extensively used as both building material and architectural detail. She attributes the provenance of marble attested at Paphos to Greece. ${ }^{9}$ Therefore, due to the state of research, the analogies for stone implements discussed in the study are mainly based on comparisons according to the function and shape of the stone object rather than the rock type.

The artefacts come mostly from two locations - Villa of Theseus and House of Aion, from the late occupation phases at Nea Paphos. ${ }^{10}$ Dating of ground stones is very difficult due to their long-term usage, lack of well dated comparative material and the fact that some of them were made of earlier architectural elements. In this instance, pottery sequences are immensely helpful in establishing the chronology of the discussed material. Based on

\footnotetext{
3 For the preliminary results on stone implements from Paphos Agora Project, see: Florek 2016.

4 Wright 1992b: 58-59.

5 Blitzer 1995; Wright 1992a.

6 Peacock 2013: 80-83.

${ }^{7}$ Hubert Kiersnowski preliminarily identified the rock type based on photos of objects.

8 Dzwoniarek 2014: 41-47.

9 Dzwoniarek 2014: 41.

10 For the general plan of the site, see: Daszewski 1999: 164.
} 
pottery evidence, some of the analysed stone implements can be dated between the fourth and fifth ${ }^{11}$ as well as sixth and seventh centuries AD. ${ }^{12}$ One cannot rule out, however, that some artefacts have an earlier origin and have been merely re-used in the late Roman period.

Due to the state of research this paper will not analyse the production techniques of these objects nor the provenance of the stones from which they were made.

\section{A FEW WORDS ON GEOLOGY}

The island of Cyprus is characterised by four main geological terrains: Kyrenia Terrain in the north, the Troodos Terrain in the central part of the island, the Cirum Troodos Sedimentary Succession, which spreads both north and south of the Troodos Terrain and the Mamonia Terrain to the south-west of the island..$^{13}$ The area of Paphos is situated on the fringes of two terrains - Mamonia and the Circum Trodoos Sedimentary Succession. ${ }^{14}$ Mamonia consists of different igneous, sedimentary and metamorphic rocks formed during the Middle Triassic and Upper Cretaceous ages. ${ }^{15}$ The second terrain around Paphos is mainly characterised by calcarenites and gypsum. ${ }^{16}$ Sandstones, on the other hand, are present in the northern part of Cyprus. ${ }^{17}$

Archaeologists are often criticised for not paying sufficient attention to geology and the physical properties of stones used in antiquity. It is not because archaeologists are not interested in this aspect, but they might not always have the right tools and methodology in place to unambiguously confirm their assumptions as to the kind of material. As mentioned in the introduction, most of the analysed objects $(c .70 \%)$ is made of calcarenite (a locally found type of limestone). The rock is mainly composed of sand-sized carbonated grains. ${ }^{18}$ It is a very porous, with little permeable qualities. The other objects are made of other types of limestone, basalt and marble.

Two limestone quarries from the Roman period have been documented in Cyprus. One of them is found in the vicinity of Paphos. According to Ben Russell, the quarry has been used in the Roman Imperial period. ${ }^{19}$

\section{SQUATTERS' WORKSHOPS}

During the 1969 season the Polish team excavated two simple structures, which were interpreted as workshops. The first one, in room 31 of Villa of Theseus, consists of an upside

\footnotetext{
11 Daszewski 1970: 128.

12 Daszewski 1972: 219.

13 GeolSurveyDep: see Introduction.

14 GeolSurveyDep: see Geological Map.

15 Atalar, Kilic 2006: 3.

16 GeolSurveyDep: see Sediments.

17 GeolSurveyDep: see Geological Map.

18 Mead, Austin 2006: 912.

19 Russell 2013: 44.
} 


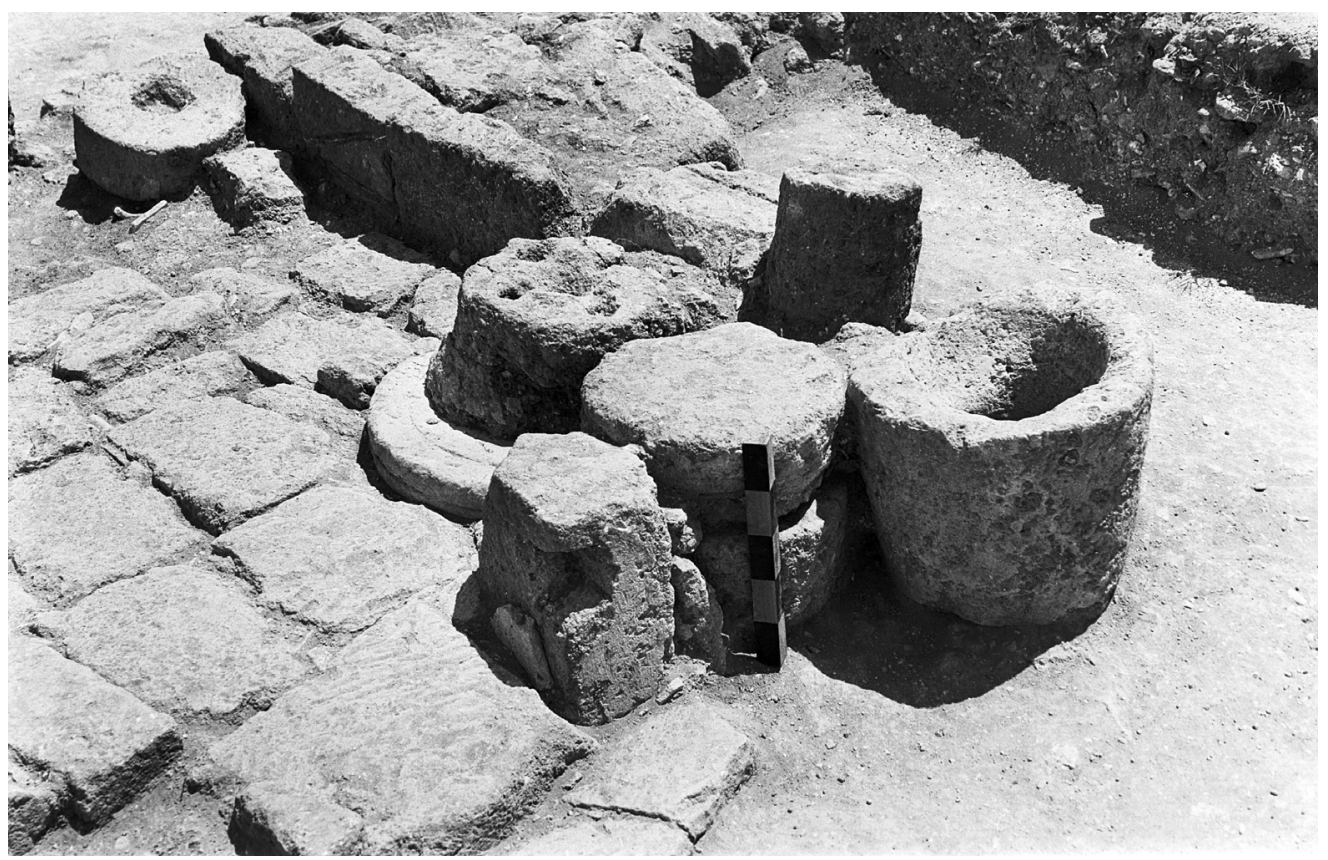

1. Squatters' workshop found in room 35 (documentary photo of the Polish Archaeological Mission to Paphos).

down marble column base and a row of three rectangular blocks. ${ }^{20}$ It has been interpreted as a primitive workshop, with the column base serving as a table. Unfortunately this workshop has been dismantled and is not located in situ any more.

Another structure consisting of six worked stones was found next to the entrance to the adjacent room 35 (Fig. 1). ${ }^{21}$ It has been described by the excavators as 'a series of mortars' ${ }^{22}$ The author would argue that the structure could also function as a workshop for grinding, storage and perhaps distribution purposes. The four main components of this workshop are: the turned upside down column base (NP SO 37) located in the centre, a circular stone (NP SO 34) beneath the column base, and a circular grinding stone (NP SO 40) to the right and another reused column (NP SO 39), with four circular sockets carved in it, situated on the left-hand side. Two other stone objects (NP SO 33 and NP SO 36) are located in a distance from the four above-mentioned.

The turned upside down column base (NP SO 37) has a diameter of almost $50 \mathrm{~cm}$ (a part seems to be broken off) and a preserved height of $22 \mathrm{~cm}$ (Fig. 2a). The use surface is rather rough and uneven. The column base is made of calcarenite. This object could also serve as a table.

\footnotetext{
${ }^{20}$ Daszewski 1970: 127.

21 Daszewski 1970: 127.

22 Daszewski 1970: 127-128.
} 

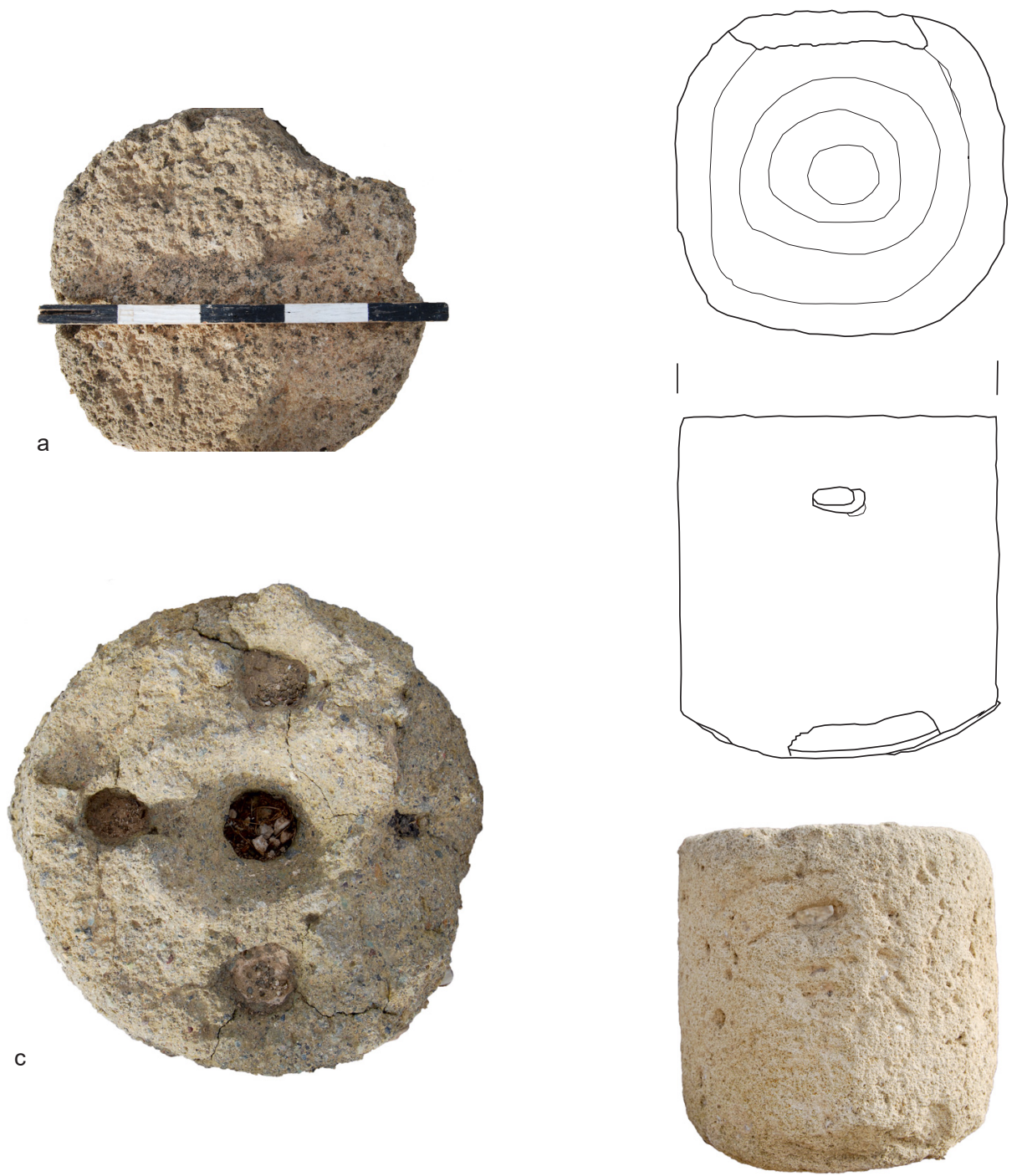

b

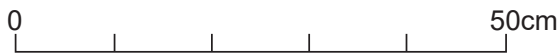

2a. Reused, turned upside down column base, inv. no. NP SO 37; b. mortar, inv. no. NP SO 40; c. unidentified round stone object with four cups, inv. no. NP SO 39 (Phot. and drawing: K. Pawlik). 
NP SO 34 is a circular object beneath the column base. Due to the fact that it was impossible to remove the stone lying on the top, complete measurements and a proper identification of the object were not possible. The recorded height is $23 \mathrm{~cm}$. It might have been an olive crusher, but without a more detailed examination (i.e. removing the upper stone), the identification is a mere speculation. It is also made from the local calcarenite.

NP SO 40 (Fig. 2b) is almost complete, except for one side, which has been cut or chipped off. It can be classified as a mortar. There is a horizontal oval hole on one side. The hole is $5 \mathrm{x} 4 \mathrm{~cm}$ as measured on the outer surface; the opening on the inner surface is somewhat wider $(7 \times 4 \mathrm{~cm})$. The use (inner) surface has been carved in stoned spirals (not very well visible); the lowest groove (or cup; see below) is $7 \mathrm{~cm}$ wide. The outer surface is rough, slightly porous. The mortar is made of calcarenite. It might have been made out of a column. It has a diameter of $39 \mathrm{~cm}$ and a preserved height of $39 \mathrm{~cm}$. The spiral marks on mortars have been generally named and classified as cup and ring marks. ${ }^{23}$ These have been mainly found on prehistoric rock mortars from north-western Europe, which can hardly be considered as a direct analogy. However, no geographically or chronologically closer analogies were found by the present author. Some similarities, at least in terms of shape, can be observed with the mortar found in Halasarna in Kos; however that mortar has no spiral grooves. ${ }^{24}$ According to David Peacock, the lowest cup was used for grinding (or pounding) and 'the spiral (ring) would be a seating for the retaining basket'. ${ }^{25}$ When not used for grinding, it could serve a secondary function as a storage vessel. Less prominent spirals have been found inside an olive oil collecting vats, for example, in Chhim, Lebanon. ${ }^{26}$ However, the above-mentioned collecting vat is twice as large as the object from Paphos. The purpose of the small hole on the side of NP SO 40 is not clear. It is too narrow for a wooden beam to pass through to carry the vessel. Perhaps the hole could serve as an overflow hole.

NP SO 39 (Fig. 2c) is an unidentified round object with four cups: three shallow $(2-3 \mathrm{~cm}$ deep) and one deeper $(5-6 \mathrm{~cm})$. The deeper one is slightly larger, $7 \mathrm{~cm}$ in diameter. The diameters of the smaller ones are between 5 and $6 \mathrm{~cm}$. The cups are rounded. The deeper cup is in the middle of the object. The other, smaller ones are located at three opposite sides. There is evidence of a fourth cup on the side that has eroded. The surface is rough, but not porous. There are many small, visible inclusions $(0.5-2 \mathrm{~cm})$. The object is made of a greyish, soft stone, most likely conglomerate. The stone has a diameter of $44 \mathrm{~cm}$, and a preserved height of $26 \mathrm{~cm}$. The author can propose two interpretations, which might explain this object's function: it could be a cup mark mortar ${ }^{27}$ or some kind of simple measures for small quantities of dry products (i.e. grain). The author inclines towards the former interpretation. Rocks with similar cups, although distant chronologically and geographically,

\footnotetext{
23 Peacock 2013: 32-33, 35.

24 Poupaki 2009: 109, Fig. 3 on page 105.

25 Peacock 2013: 34.

26 Waliszewski 2014: 421, 423.

27 Peacock 2013: 31-33.
} 
3. Rectangular block, possibly part of an olive oil press, inv. no. NP SO 36 (Phot. K. Pawlik).

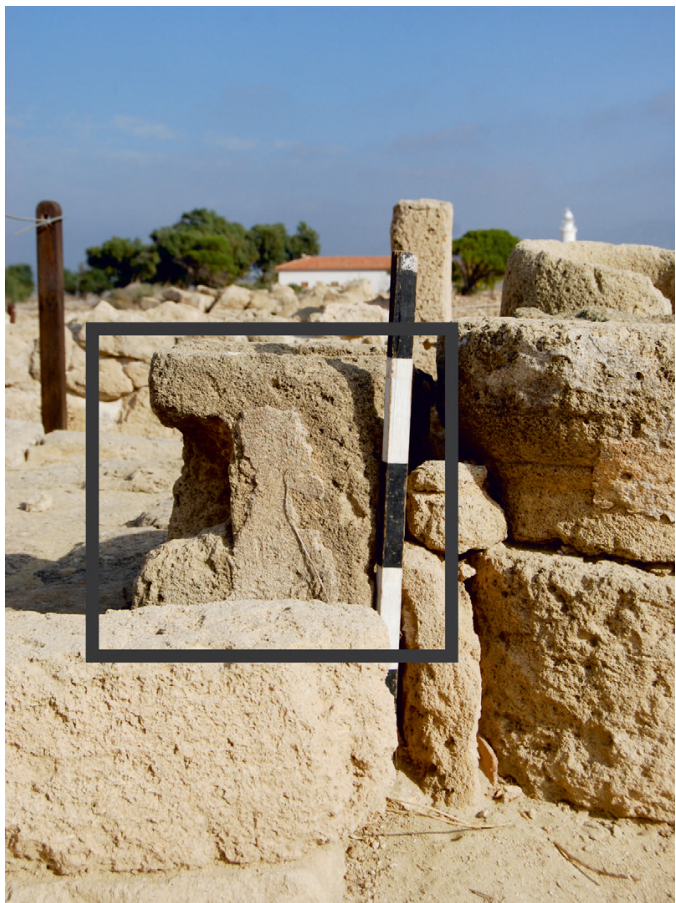

have been used for grinding and pounding fruit, berries or other vegetables. ${ }^{28}$ Based on the diameter of object NO SO 39, it seems that fruits rather than vegetables were ground. In East Africa these cups were also used for crushing quartz or shattering small pieces of iron ore. ${ }^{29}$ On the other hand, the use of such cups as simple measures could explain the subtle difference in their diameter. This interpretation is based on marble measures from other sites in the Mediterranean. ${ }^{30}$

NP SO 36 is a rectangular block with a rectangular mortise $-18 \mathrm{~cm}$ deep and $12 \mathrm{~cm}$ wide (Fig. 3). Some beige plaster can be found on the front side of the object. The surface is rough, porous. The rock type was not successfully identified. The block has the following dimensions: $25 \mathrm{~cm}$ length, $50 \mathrm{~cm}$ width and $29 \mathrm{~cm}$ height. The object was moved from its original location during the creation of the archaeological park and placed above another stone, next to the discussed workshop. It could be a dovetail beam niche mortise (part of an olive oil press installation) but it does not match any of the examples from the Mediterranean compiled by Raphael Frankel. ${ }^{31}$

NP SO 033 could be an unfinished oval crushing stone (more precisely a crusher) with a square-like socket. The object was found a few meters away from the workshop (Fig. 4a).

\footnotetext{
28 Peacock 2013: 31 .

29 Peacock 2013: 31.

30 Gwiazda 2014: 41.

31 Frankel 1999: Appendix B.
} 

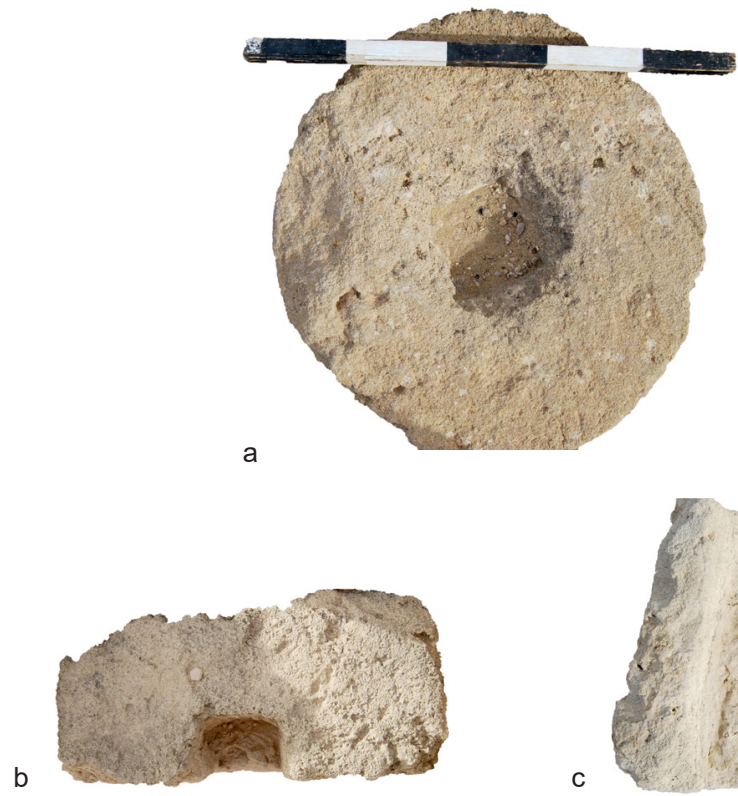

C
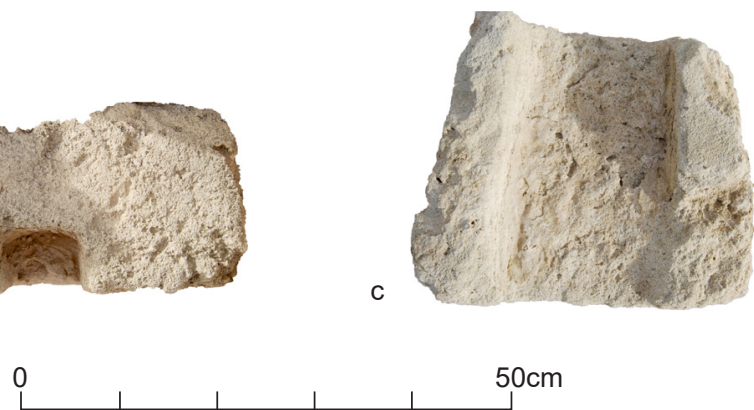

4a. Crushing stone, inv. no. NP SO 33; b. rectangular block, part of an olive oil press, inv. no. NP SO 38; c. a stone object with a large flat central part and raised edges on two opposite sides, inv. no. NP SO 35 (Phot. K. Pawlik).

The surface is rough with white inclusions or pieces of plaster $(0.5-1 \mathrm{~cm})$. The object is made of calcarenite. It has a diameter of $45-47 \mathrm{~cm}$ (the outer surface is irregular); the preserved height is $18 \mathrm{~cm}$. The square socket's side is $12 \mathrm{~cm}$. The opening on the other side cannot be unquestionably determined. Therefore, the object cannot be precisely identified. Crushing stones were used in the first stage of the olive oil production process. Olives were crushed by the rotation of stone in a crushing basin. A wooden beam was placed in the square socket and probably fixed with some metal or wooden mount. According to Frankel's nomenclature, such a crushing stone was part of a crushing device with a far side of the vertical axis. ${ }^{32}$ The crushing stone was likely reused as a building block during the squatters' settlement phase.

During the construction of the archaeological park in Paphos, some stone artefacts have been moved around and a few were brought into the area of the workshop. They will not be taken into account when interpreting the function of the workshop.

The first of them is NP SO 38 (Fig. 4b), a rectangular block with a rectangular mortise. The surface is rough, porous. One side of the object is mostly covered with grey plaster.

\footnotetext{
32 Frankel 1999: Appendix B.
} 
It is made of calcarenite and measures $34 \times 40 \times 24 \mathrm{~cm}$. The mortise is $9 \mathrm{~cm}$ deep, $14 \mathrm{~cm}$ wide. The block resembles object NP SO 36. It has been re-used as building material.

NP SO 35 is a stone object with a large flat central part and raised edges on two opposite sides (Fig. $\mathbf{4 c}$ ); one of them is eroded. The object has a rough, porous surface. Some grey plaster can be noticed on the sides. It is made of white limestone, somewhat different from calcarenite. The object has the following dimensions: $35 \times 36$ x $18 \mathrm{~cm}$. Its function remains enigmatic. A similar object with higher walls has been found at Panayia Ematousa. ${ }^{33}$ It has been classified by Lena Jacobsen as a boulder-size weight. However, the bases of such identification remain unknown.

The above-discussed workshop occupied the front of room 35 of Villa of Theseus; archaeological evidence suggests that during the squatters' phase of occupation the rear part of the room was already blocked..$^{34}$ Basing on pottery, this rearrangement took place in the late Roman period. The workshop can be classified as an independent working station, as other squatter installations were located in rooms further afield. Given the scarce evidence of olive oil press elements, it seems rather unlikely that the workshop was connected to this industry. The author suggests that the processing of some dry goods (e.g. fruits), grain or even metal ore was the purpose for establishing this modest facility. There are two possibilities as to how this workshop could have functioned. Goods could have been placed in the cup and ring mortar, ground, then placed on the table to be scaled in the provisional measures. Alternatively, the object with the rounded cups to the left of the table and the cup and ring mortar to the right were used to grind or pound different goods, which later could have been placed on the table and distributed.

Some parallels to the workshop can be found in Sagalassos, where the western portico of the Agora has been transformed into workshops and shops in the second half of the fifth century $\mathrm{AD}^{35}$ and the Terrace Building was divided into smaller workshops and shops in the sixth century AD. ${ }^{36}$ It cannot be unequivocally stated that the workshop from Paphos was used for smelting ore like those from Sagalassos, but certainly some industrial activity took place there.

\section{POMPEIAN MILLSTONES}

Very few fragments of Pompeian mills (known also as hourglass mills) were found in Paphos. One upper part - catillus - of the hourglass mill and the one lower part known as meta have been recorded. The author is unable to present any measurements, because the identification and analysis of the two fragments were solemnly based on the photos provided by Henryk Meyza. There is also another stone object - NP SO 01, which to some extent resembles an upper part of a Pompeian mill.

\footnotetext{
33 Jacobsen 2005: 412-413.

34 Daszewski 1970: 128.

35 Jacobs 2009: 210, 240, Fig. 7; Waelkens et al. 2006: 236-237.

36 Jacobs 2009: 211.
} 


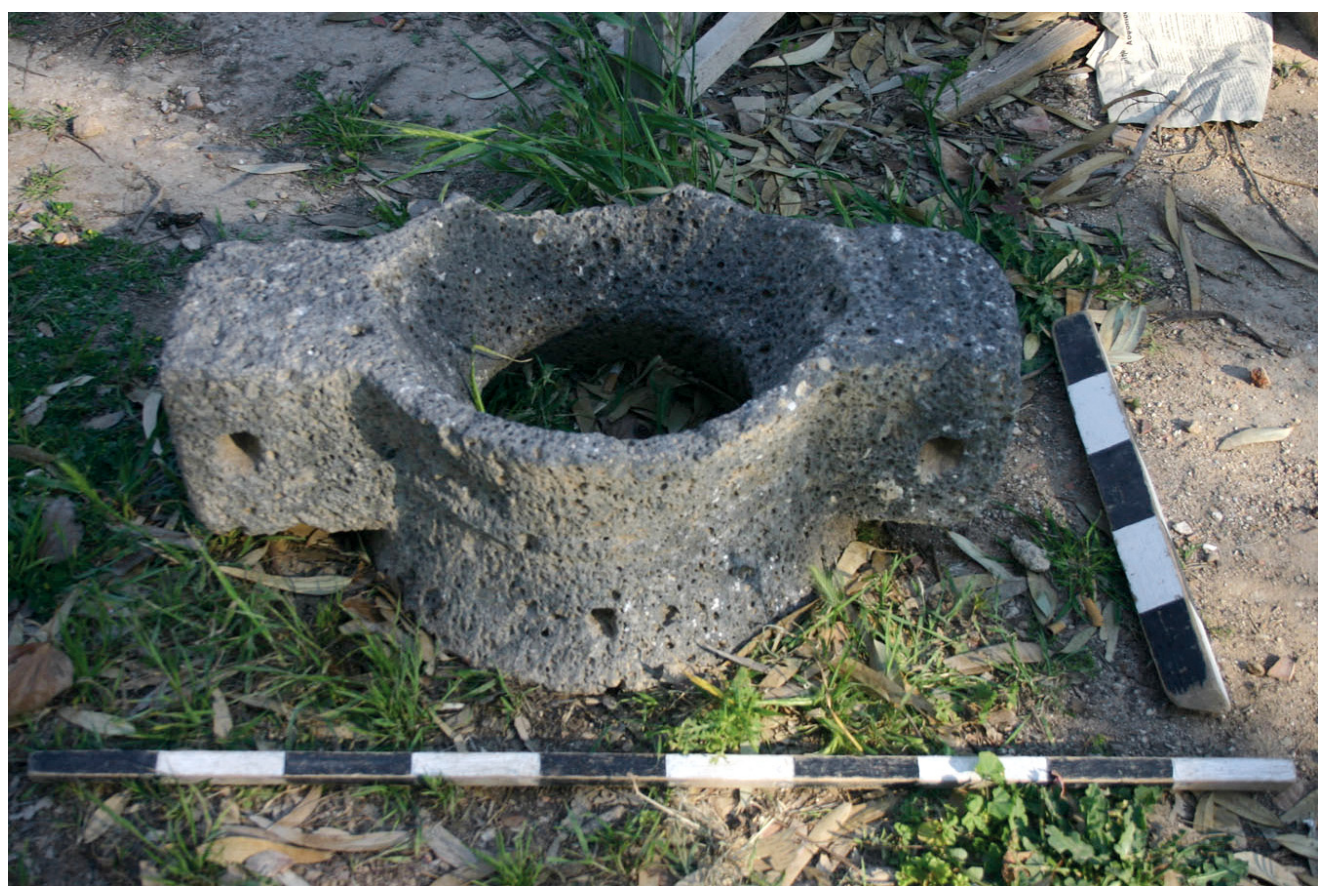

5. Part of a catillus from a Pompeian mill, inv. no. NP SO 49 (Phot. A. Brzozowska).

NP SO 49 (Fig. 5) is a central part of an upper hourglass mill. The hopper and the grinding surface are missing. The cube-like mounts have openings. On the mounts' front side a square socket is visible. Smaller, circular mortises are hewn on the two remaining sides of the mount. An external band goes around the midsection of the catillus. The inside is carved with numerous curved furrows. The object is made of basalt.

The custom of dressing millstones was practiced throughout Antiquity. However, it is not common to find any form of furrows or other patterns on Pompeian mills. So far very few examples of dressing have been found on Pompeian mills ${ }^{37}$ and according to some researchers it was useless in terms of function. ${ }^{38}$ Just a few examples of dressing inside catilli can be found, ${ }^{39}$ but these specimens differ in rock type and dressing pattern from the one found in Paphos. Usually, dressing of upper and lower stones of millstones helped to maintain the sharpness of the utensil. ${ }^{40}$ The finds from across the Roman Empire suggest that neither the rock type, nor the type of the millstone (although they were mainly found on rotary querns) determine the dressing pattern. ${ }^{41}$ This aspect of the technological process of millstone production requires further analysis.

\footnotetext{
${ }^{37}$ Lepareux-Couturier 2014: 152.

38 Moritz 1958: 79.

39 Lepareux-Couturier 2011: 422.

40 Lepareux-Couturier 2014: 149.

41 Lepareux-Couturier 2014: 154.
} 


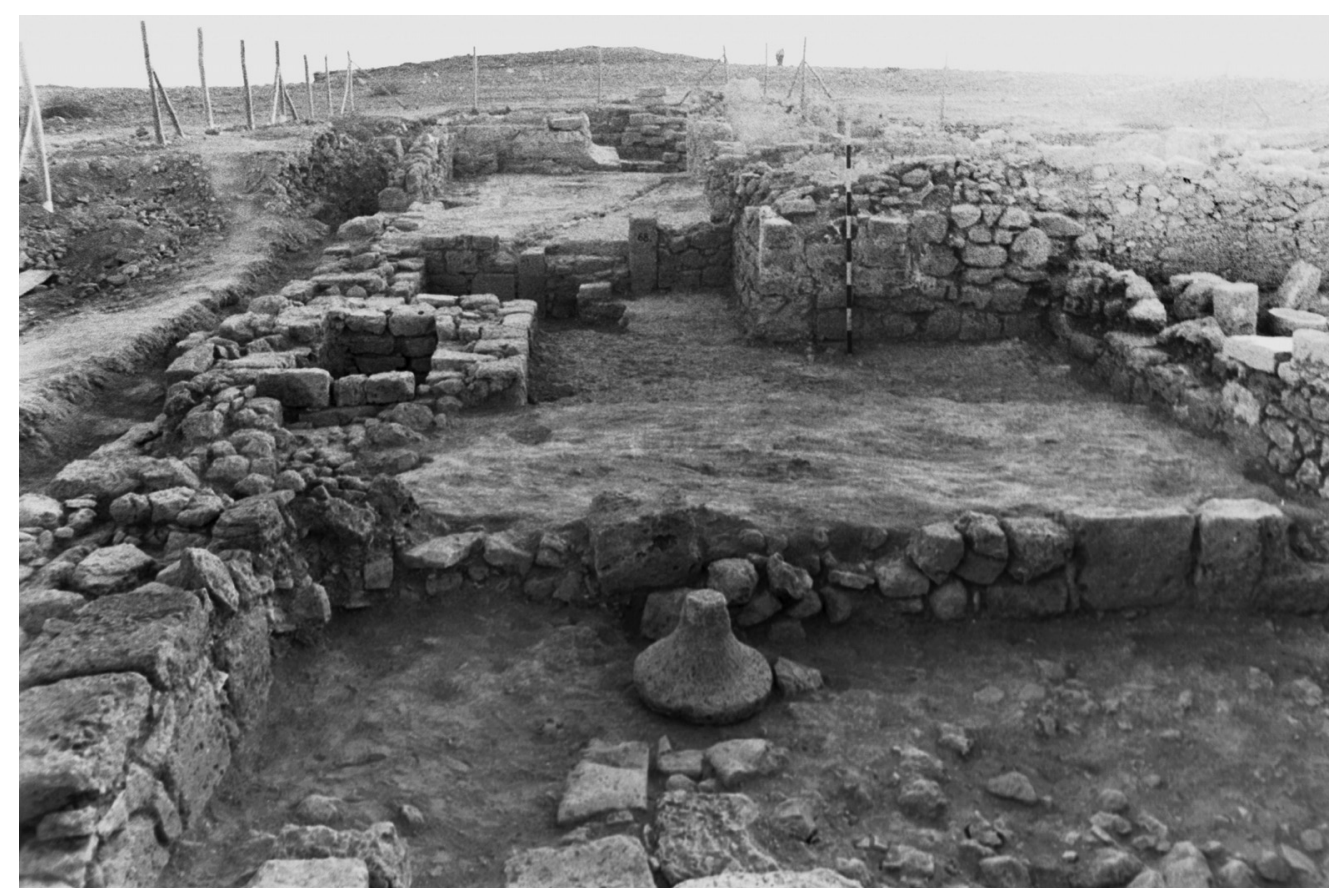

6. Meta from a Pompeian mill, inv. no. NP SO 50 (documentary photo of the Polish Archaeological Mission to Paphos).

The above described object seems to fit Peacock's type $3 b .{ }^{42}$ This type is represented by millstones smaller than other documented catilli from Pompeii. They are quite common in the Middle East. ${ }^{43}$ Their dating is dubious, but they seem to become frequent in the Eastern Mediterranean between the first and the second centuries $\mathrm{BC}$ and continue into the Byzantine period. ${ }^{44}$ There is evidence from elsewhere in Cyprus ${ }^{45}$ that such specialised implements were imported either from Lake Tiberias or northern Syria, where basalt was easily accessible.

NP SO 50 is a meta, the lower part of the hourglass mill (Fig. 6). The working surface is convex, with the top part being flat, rather than rounded. The podium is very low, it flattens towards the edges. The type of rock cannot be unequivocally determined. However, the evidence presented by Olwen Williams-Thorpe and Roger Thorpe suggest that these installation were made of basalt. ${ }^{46}$ No dressing pattern has been observed on NP SO 50, which could mean that the aforementioned catillus was not complementary

\footnotetext{
42 Peacock 1989: 207.

43 Peacock 2013: 92.

44 Peacock 2013: 92-93.

45 Williams-Thorpe, Thorpe 1993: 263.

46 Williams-Thorpe, Thorpe 1993: 273.
} 

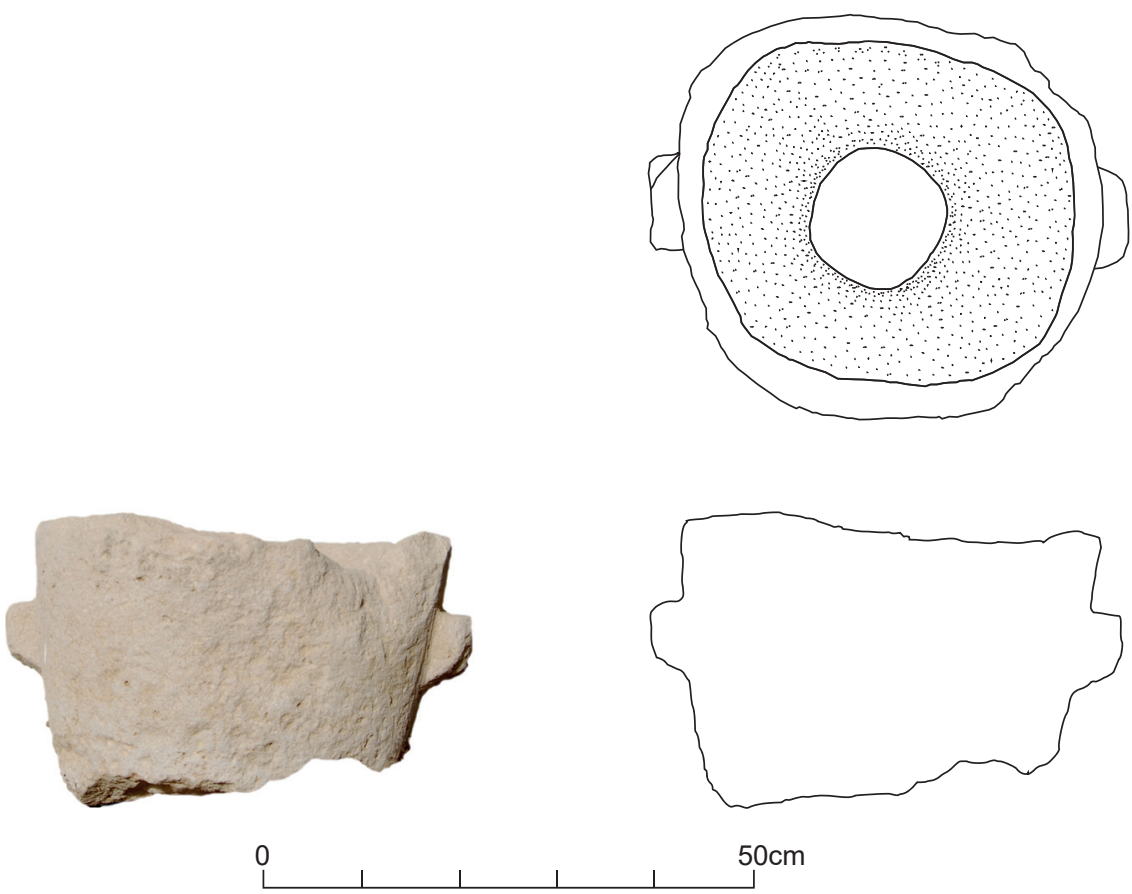

7. Unidentified stone object, perhaps an unfinished upper part of a Pompeian mill, inv. no. NP SO 01 (Phot. and drawing: K. Pawlik).

to the discussed meta. This assumption is based on well-preserved and complete rotary querns with both the upper and the lower stones covered by dressing patterns on use surfaces. ${ }^{47}$

Metae appear in various shapes and so far no one has pointed out any correlation between a specific shape of a catillus and meta. Based on the shape and stylistic similarities, the closest analogy for the above-discussed specimen from Nea Paphos comes from a press room in Ashkelon. ${ }^{48}$

In a fully functioning hourglass mill the catillus was placed on top of the meta. The upper part of the catillus served as a hopper, and the lower as a grinder. Two wooden beams would be fixed into the square sockets and held in position by bolts in the mortises. The entire construction was secured by a wooden frame. The mill was powered by animals, donkeys or mules, and to a lesser extent by humans. The end of Pompeian mills' production is difficult to determine. Examples from the Eastern Mediterranean indicate that some smaller mills of this type could have been used until the Late Roman period. ${ }^{49}$ The meta

\footnotetext{
47 Lepareux-Couturier 2014: 155.

48 Israel 2009: 358.

49 Peacock 2013: 93.
} 


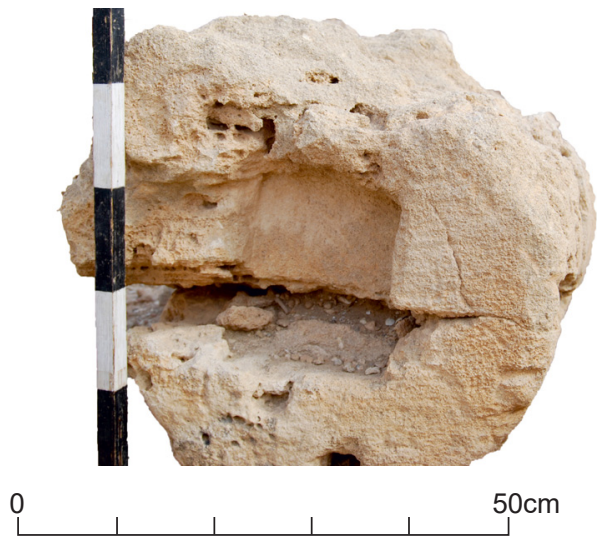

8. An element of a press weight(?), inv. no. NP SO 44 (Phot. K. Pawlik).

described above has been found in a late Roman context; however it is not certain whether the object was still in use at the time.

NP SO 01 is an object similar in appearance to the upper part of a Pompeian millstone (Fig. 7). It is fragmentarily preserved. The mounts are cuboid in shape. The use surface is smooth, unlike the outer surface, which is rough. The object is made of limestone. It has a diameter of $45 \mathrm{~cm}$; its preserved height is $29 \mathrm{~cm}$. The mounts are $15 \mathrm{~cm}$ wide and $8 \mathrm{~cm}$ long.

Although, one can observe some similarity of NP SO 01 to the hourglass mills, it differs clearly from NP SO 49 in a morphological term: NP SO 01 lacks sockets in the mounts, hence no wooden beam could be inserted into the object to put it in motion. Moreover its shape is more conical than hourglass-like. However, these might be because the millstone is unfinished. Finally, the majority of Pompeian mills were made of basalt; limestone is not a common choice for such objects. This could mean that the analysed object is a testimony of the local community's craftsmanship.

\section{ELEMENTS OF OLIVE OIL PRESSES/PRESS WEIGHTS}

NP SO 44 might be an element of an olive oil press - perhaps a lever and screw weight (Fig. 8). The discussed example comes from the House of Aion and is fragmentarily preserved. The surface of the object is porous and the object itself is poorly preserved; its upper part is almost split in half. The square mortise is not well worked. The object is made of calcarenite and measures $51 \mathrm{~cm}$ in diameter and $58 \mathrm{~cm}$ in height.

The lever and screw weight olive oil press was introduced in the Roman Empire in the second quarter of the first century AD. ${ }^{50}$ The discussed press weight most likely belongs to

\footnotetext{
50 Lewit 2007: 119-120.
} 
type 7 of Frankel's classification ${ }^{51}$ and type G.6 according to Waliszewski's typology. ${ }^{52}$ It is also known as Luvim type screw weight. Analogies can be found on the Palestinian coast and around Mount Carmel, Israel. ${ }^{53}$ This might suggest that NP SO 44 could be either an import or a local imitation.

\section{BASINS/BOWLS}

Fragments of basins are among the most common group of stone objects found in the last occupation phase of Villa of Theseus. They appear in two shapes: rectangular and circular or oval. One can distinguish five main types, mainly based on the shape and thickness of walls:

- type A - basins with thick walls, irregular, rectilinear in shape but otherwise not homogenous in terms of shape; these were made predominately of tufa or local calcarenite;

- type B - rectangular in shape basins, with thick, straight walls. The difference between this and the previous type is mainly in manufacture: one can observe that this vessel (one fragment has been identified) is more refined than basins of type A;

- type C - shallow, rectangular basins;

- type D - small, rounded bowls with a diameter less than $30 \mathrm{~cm}$;

- type E - large, shallow bowls with visible, but not well-marked rims.

Circular or oval vessels (types D and E) are less common than rectangular basins (types A, B and C). Most of the vessels are made of calcarenite, with a few exceptions, produced from some other type of limestone. It is likely that particular types of basins had different functions: some of them were storage vessels but others could have been used for processing food or minerals (see also below).

TYPE A

NP SO 18 is a basin with a thick rim (Fig. 9a). The object is quite irregular, rectilinear in shape. It is very eroded, with large holes on one side (up to $2 \mathrm{~cm}$ wide). The rim is fragmentarily preserved. The inner surface ${ }^{54}$ is smoothened and bottom is covered by a layer of plaster. The bottom is not even, but is lowering towards one end. The basin is made of some type of porous limestone or tufa. It is $43 \mathrm{~cm}$ long, $34 \mathrm{~cm}$ wide and has a preserved height of $19.5 \mathrm{~cm}$.

NP SO 15 is a fragment of a rectilinear basin with a thick rim (Fig. 9b). The edges are rounded. The interior is porous. The vessel is rather poorly manufactured. It is made of calcarenite. Its dimensions are: length $21 \mathrm{~cm}$, width $22 \mathrm{~cm}$ and height $10 \mathrm{~cm}$.

51 Frankel 1999: 150.

52 Waliszewski 2014: 163.

53 Frankel 1999: Appendix B.

54 In the case of basins and bowls the author does not use the term use surface, but inner surface, because, in most of the cases, this surface does not bear traces of usage. 


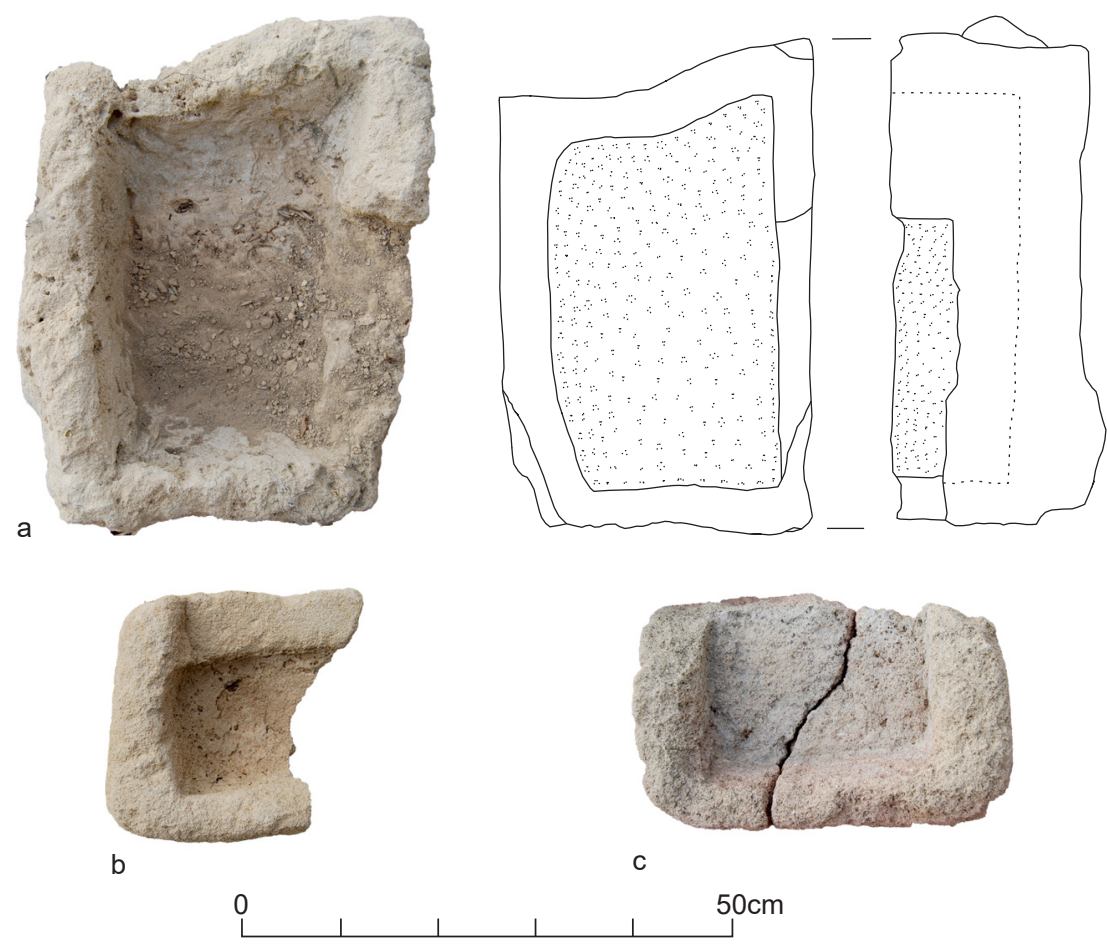

9. Basins: a. inv. no. NP SO 18; b. inv. no. NP SO 15; c. inv. no. NP SO 17 (Phot. and drawing: K. Pawlik).

NP SO 17 is a fragment of a basin, preserved in two pieces (Fig. 9c). The inner surface is porous. It has a thick rim and its edges are rounded. It is made of some sort of limestone (with shades of grey and reddish). Its dimensions are: length $20 \mathrm{~cm}$, width $33 \mathrm{~cm}$ and height $17 \mathrm{~cm}$.

According to a number of authors ${ }^{55}$ this type of basin was a substitute for press beds. However, other scholars ${ }^{56}$ argue that such basins were used as water containers or troughs for animals. Analogies supporting the last interpretation can be found both on late Roman sites on Cyprus ${ }^{57}$ and in Syria. ${ }^{58}$ Therefore, the last function is plausible. According to Wiktor Daszewski ${ }^{59}$ small enclosures for animals were constructed in some rooms $(16,28$ and 29) of the Villa of Theseus in the later phase of occupation. Six enclosures have been recorded in the western wing of the villa. For example, enclosure no. 1 (built in the

55 Jacobsen 2005: 412-413; originally the hypothesis was formed by Sophocles Hadjisavvas (Hadjisavvas 1992: 55-59).

56 Mango 2008: 78.

57 Jacobsen 2005: 414-415.

58 Mango 2008: 88.

59 Daszewski 1970: 124. 
north-western corner of room 28) has $1.44 \mathrm{~m}^{2}$. So modest dimensions could indicate it was used for keeping small livestock. Furthermore, the walls that make up the enclosure have a maximum height of just over $50 \mathrm{~cm}$. Given the archaeological context in which some of the type A basins were found, it can be assumed that a number of them were used as troughs. On the other hand, NP SO 18 could have been a simple water container, as there is evidence of plaster inside it.

TYPE B

NP SO 14 is a fragment of a rectangular in shape basin (Fig. 10a). Its outer surface is exceptionally smooth. The inner surface is more porous. The object is made of some type of limestone, other than calcarenite. The preserved dimensions are: length $24 \mathrm{~cm}$, width $19 \mathrm{~cm}$ and height $10.5 \mathrm{~cm}$.

Analogous examples from Panayia Ematousa seems to be somewhat shallower than vessel from Nea Paphos, and have wider rims than NP SO $14 .{ }^{60}$ This type could have been used for similar purposes as type A basins.

TYPE C

NP SO 16 is a fragment of a basin (Fig. 10b), flatter and wider than the other examples from Nea Paphos. The rim has a rectilinear shape. The inner surface on one side is smoothened to some extent, which might suggest that it has been worked. The basin is made of sandstone. It is fragmentarily preserved, having the following dimensions: width $25 \mathrm{~cm}$, length $43 \mathrm{~cm}$ and height $8 \mathrm{~cm}$.

A similar object has been identified in late Roman Sardis, in a re-used apsidal room of a residential building. ${ }^{61}$ In the late Roman period the room fulfilled simple industrial purposes - Marcus Rautman identified hearths, ovens, vats etc there. ${ }^{62}$

NP SO 16 looks more refined than other basins from Nea Paphos, which may possible indicate a work of a different artisan. Based on the morphology of the vessel, the author would suggest it could have been used to either soak or rinse cloth or other products.

TYPE D

NP SO 20 is a small round bowl, preserved in two fragments (Fig. 10c). The rim is not very well-marked. The surface is very rough, porous. The inner surface bears traces of peck marks. The vessel is made of calcarenite. It is $29-30 \mathrm{~cm}$ in diameter and the preserved height is $16 \mathrm{~cm}$.

\footnotetext{
60 Jacobsen 2005:412-415.

61 Rautman 2011: 25.

62 Rautman 2011: 25.
} 


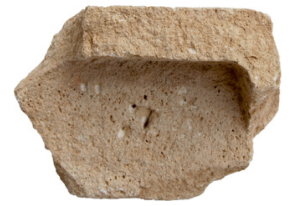

a
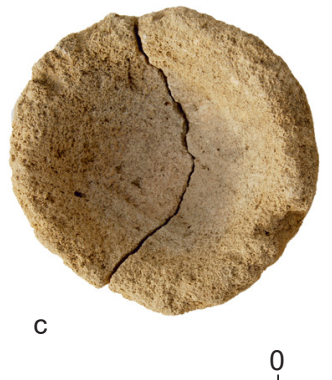
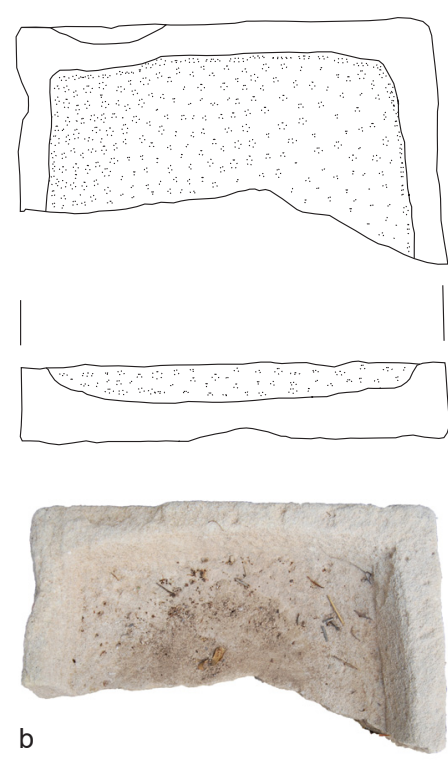

b
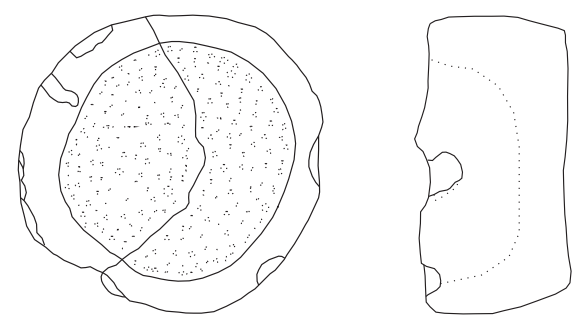

$50 \mathrm{~cm}$

10. Basins: a. inv. no. NP SO 14; b. inv. no. NP SO 16; c. inv. no. NP SO 20 (Phot. and drawing: K. Pawlik).

It was found during the 1970 excavation season, in the debris of one of the kilns built in the late phase of Villa of Theseus. Perhaps it was used to store the burnt lime or functioned as a crucible. No direct analogies are known.

\section{TYPE E}

NP SO 03 is a large shallow oval bowl preserved in three fragments (Fig. 11a). The rim is partly eroded. The inner surface of the vessel is not even but its central part is smoothened; the bottom is thinner than the other walls. The bowl is made of calcarenite. It is $49 \mathrm{~cm}$ long and $44 \mathrm{~cm}$ wide; the preserved height is $5 \mathrm{~cm}$. It might have been use as a mortar, given the smoothened inner surface. Alternatively, it functioned as a large plate for food. 

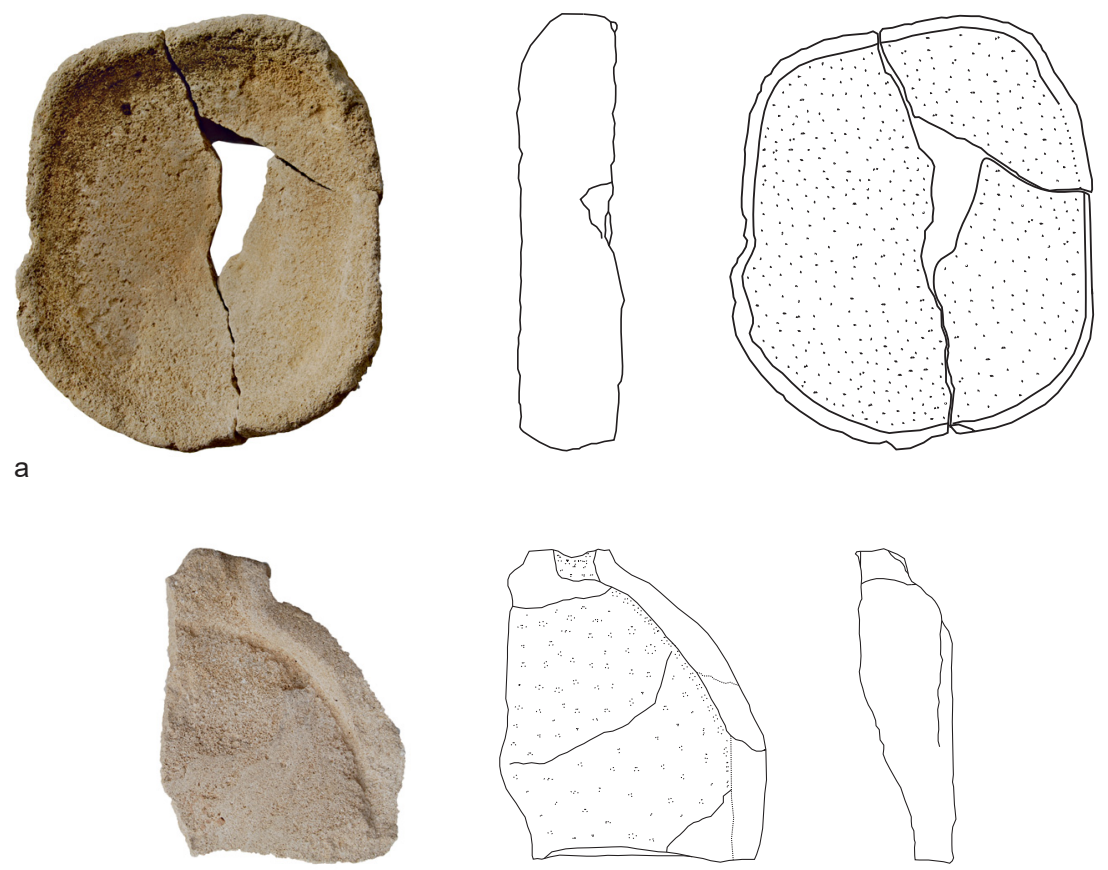

b
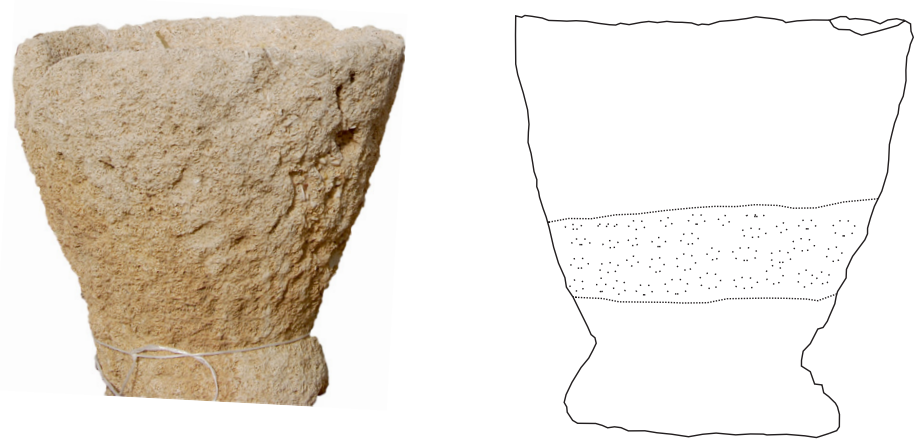

C

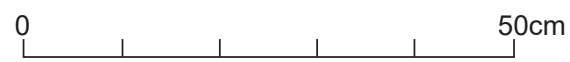

11a. Broken bowl, inv. no. NP SO 03; b. bowl, inv. no. NP SO 09; c. unidentified container, inv. no. NP SO 02 (Phot. and drawing: K. Pawlik). 
NP SO 09 is a fragment (more than a quarter of the original vessel is preserved) of an oval, flat bowl (Fig. 11b). The rim is well marked with a groove immediately below (the inside of the vessel). A square knob is preserved on the side of the vessel. Its surface is rather rough and eroded, hence the final identification whether it is a handle or a spout is not possible. The object is made of limestone other than calcarenite. The preserved length is $32 \mathrm{~cm}$, width $-27 \mathrm{~cm}$ and height $-10 \mathrm{~cm}$. An analogical vessel was found in Panayia Ematousa. ${ }^{63}$ Lena Jacobsen has identified it as a bowl with a knob. According to her, this bowl was very similar to the one found in Salamis, with the difference that specimen from the latter location was made of marble. ${ }^{64}$ Generally marble bowls from Salamis are deeper and have a triangular knob.

If the knob at the rim of NP SO 09 had functioned as a spout, then the vessel was most probably used for extracting juices from fruits or vegetables.

NP SO 02 is clearly different than all the other basins and bowls (Fig. 11c). It has the shape of a reversed cone, with a footer as a base. The bottom of the base is flat. The surface is very rough, with many inclusions. Most of them are of organic nature, e.g. shells. Some of them are up to $3 \mathrm{~cm}$ large. The object is made of calcarenite. It has $36 \mathrm{~cm}$ in diameter and the preserved height is $36 \mathrm{~cm}$. This seems to be a sort of container. It was found filled with debris. No traces suggesting its original content were detected. It is without analogies. The fact that calcarenite is a rather permeable type of rock could indicate that something more solid was stored in the vessel.

\section{MORTARS}

Fragments of mortars are not numerous among the stone finds. They form an inhomogeneous group.

NP SO 13 is a fragment of a small rounded mortar (Fig. 12a). It has no marked rim. The use surface is smoothened, bearing traces of grinding. The mortar has a square knob on the outside. It is made of basalt, has some large red and white particles and quite a lot of mica (based on visual inspection). Its diameter is $c .30 \mathrm{~cm}$ and preserved height $-7 \mathrm{~cm}$. This small mortar is an imported ware as there are no basalt quarries in Cyprus.

NP SO 48 is a complete mortar (Fig. 12b). Its shape is irregular; the use surface forms a $3 \mathrm{~cm}$ deep bowl. The object is made of limestone. It has the following dimensions: length $30 \mathrm{~cm}$, width $27 \mathrm{~cm}$ and height $9 \mathrm{~cm}$.

A very similar, but more rounded mortar has been found in Panayia Ematousa. ${ }^{65}$ Lena Jacobsen points out that all mortars at the site were found in Hellenistic and early Roman contexts. The object from Nea Paphos comes from a later context.

\footnotetext{
63 Jacobsen 2005: 416-417.

${ }^{64}$ Chavane 1975: 13, Pl. 1.

65 Jacobsen 2005: 409-410.
} 


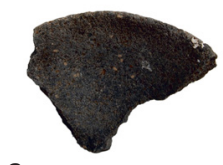

a

b
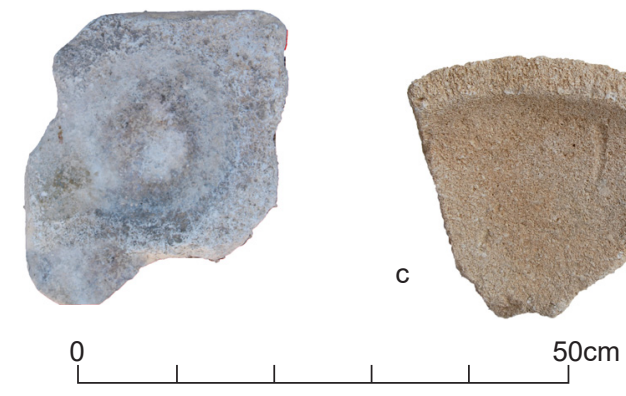

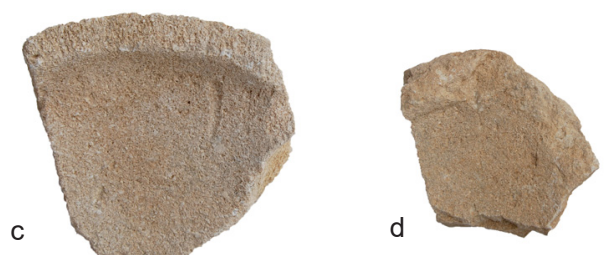

$50 \mathrm{~cm}$

12. Mortars: a. inv. no. NP SO 13; b. inv. no. NP SO 48; c. NP SO 11; d. inv. no. NP SO 10 (Phot. K. Pawlik).

The other three mortars are very similar to each other. Their characteristic feature is a flat rim. NP SO 11 (Fig. 12c) has a well-defined rim, rectangular in section. The surface is rough, but not eroded. The object is made of limestone. It is fragmentarily preserved, with a diameter of $c .40 \mathrm{~cm}$ and preserved height $-11.5 \mathrm{~cm}$. There are some traces of plaster on its use surface.

A very similar object has been found at Salamis. ${ }^{66}$ Marie-José Chavane interpreted it as a round bowl and suggested it was used in the Roman period (first-third centuries AD).

NP SO 10 is another fragmentarily preserved mortar (Fig. 12d). Its use surface is flat. The rim, flat and well-distinguished, is poorly preserved. The object is made of limestone. Its diameter is $c .40 \mathrm{~cm}$ and preserved height $-10 \mathrm{~cm}$.

NP SO 24 is a fragment of a flat mortar, very similar to NP SO 10. However, the two implements are not parts of the same mortar. The surface is very rough, porous. A small part of a well-marked rim is preserved. It is quite thick $(c .9 \mathrm{~cm}$; a precise measurement was not possible, due to the preservation of the rim). The mortar has a flat use surface, tilted only close to the rim. It is made of limestone (most likely calcarenite). Its diameter is $c .40 \mathrm{~cm}$ and preserved height $-14 \mathrm{~cm}$.

The smooth use surface seems to indicate that these three objects were used as mortars or grinding slabs, simple grinding tools intended for individual households rather than for collective food production. The lack of more sophisticated milling installations could reflect the modest needs of a small community.

\section{SPOLIA}

In the squatter phase at Nea Paphos architectural elements have been reused in two different manners: firstly, as building material; secondly, they have been redesigned or reworked to served as bowls, basins and grinding stones.

\footnotetext{
${ }^{66}$ Chavane 1975: 15, Pl. 2 (object 10).
} 

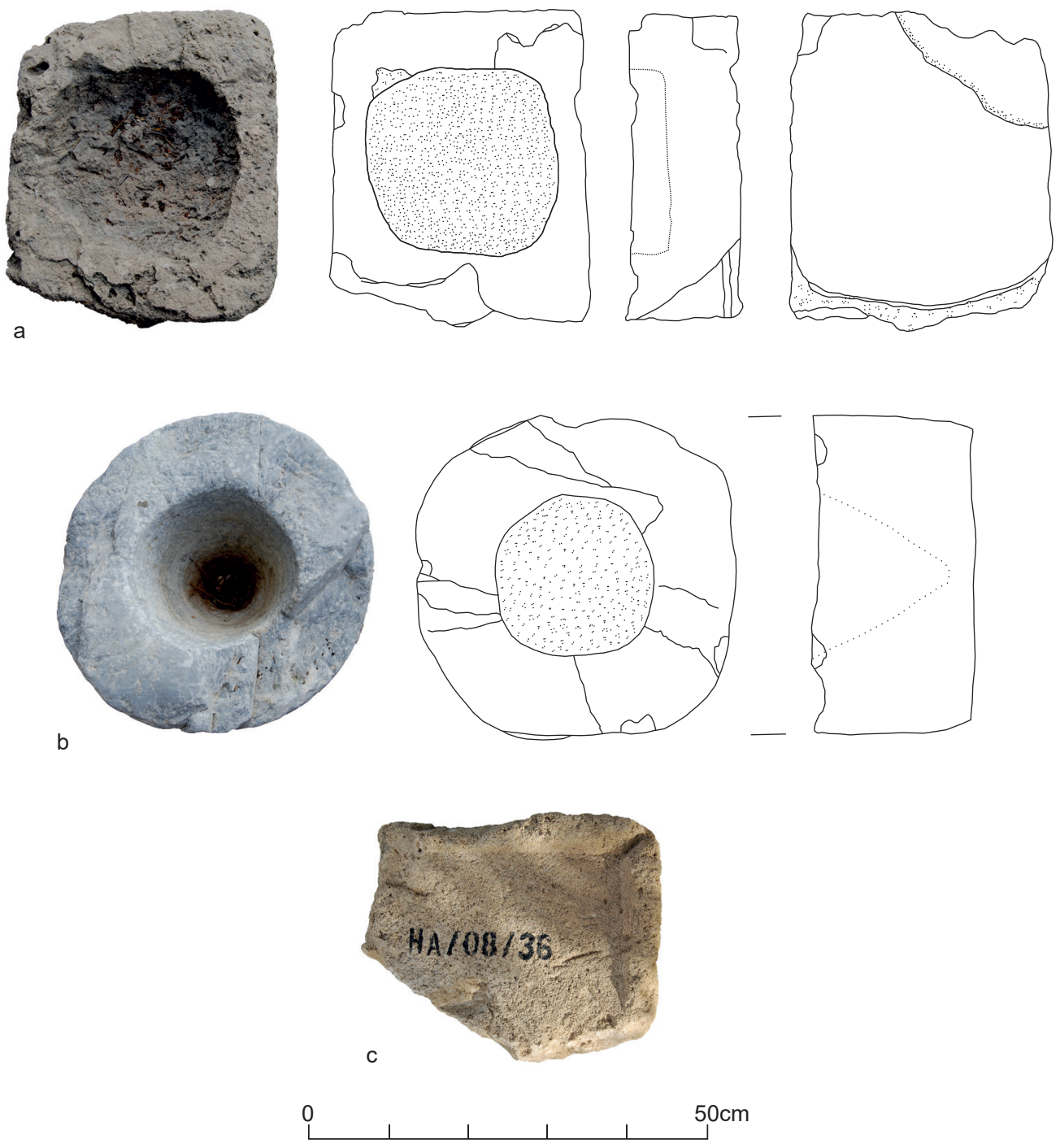

13a. A bowl with a square-like rim - hewn from a column base - with a square podium, inv. no. NP SO 04; b. column shaft, most likely turned into a mortar, inv. no. NP SO 22; c. column base with a shallow basin, inv. no. NP SO 25 (Phot. and drawing: K. Pawlik).

NP SO 04 is a bowl with a square-like rim and a square podium hewn from a column base (Fig. 13a). The inside of the bowl is irregular in shape; its diameter is $24 \mathrm{~cm}$ and a maximum depth $-5 \mathrm{~cm}$. The surface is very rough and eroded. The rock used for manufacturing this object is not attested otherwise in the assemblage from Nea Paphos. It might be tufa. The square podium's dimensions are: $38 \mathrm{~cm}$ long, $35 \mathrm{~cm}$ wide and $14 \mathrm{~cm}$ high. There are no indication as to the what could have been stored in this shallow 

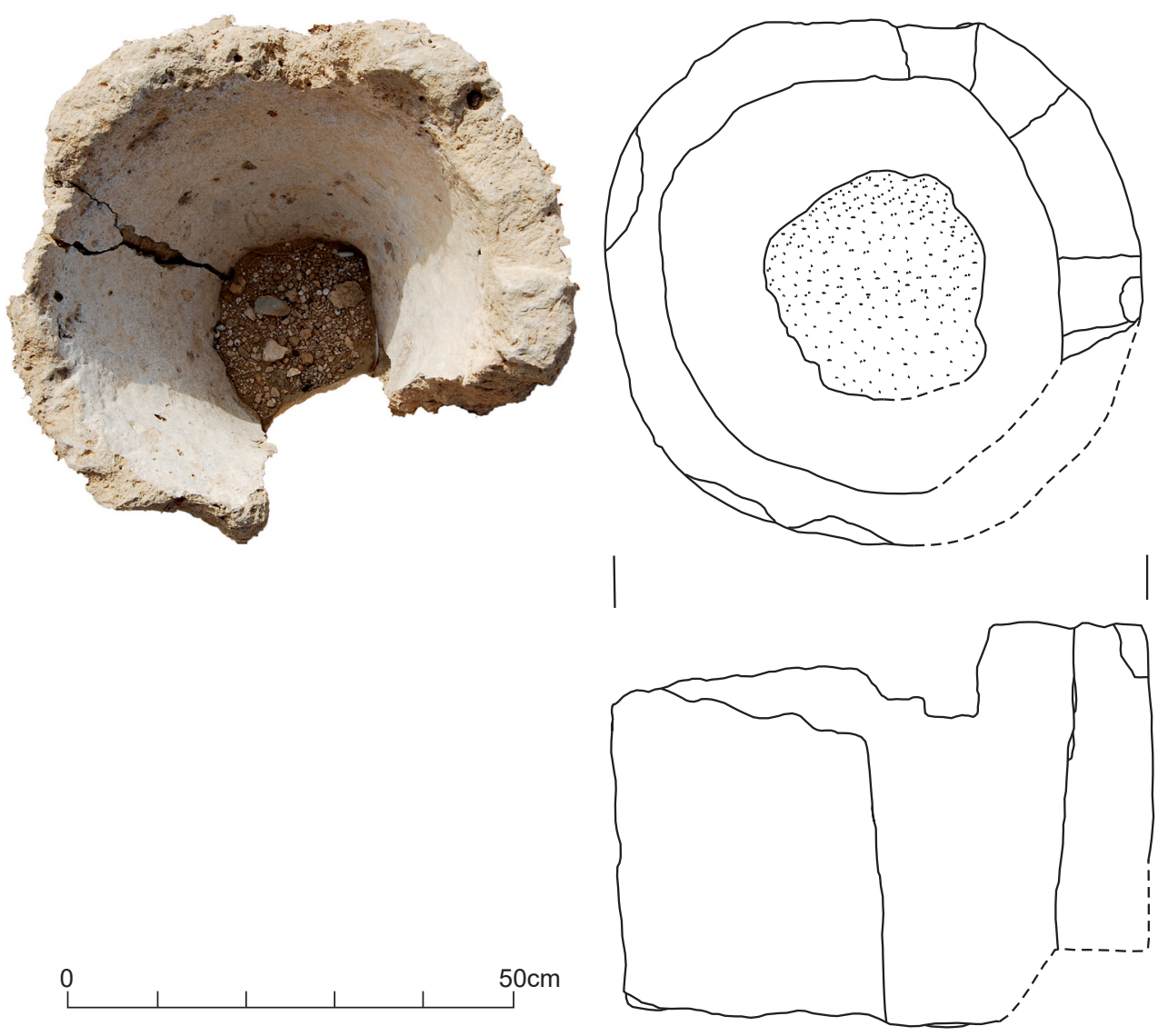

14. Column base with a shallow basin, inv. no. NP SO 42 (Phot. and drawing: K. Pawlik).

bowl. The unclear find context does not help in any way in reconstruction of the vessel's function.

NP SO 22 is a column shaft with a drilled conical opening in the centre (Fig. 13b). The object was made of oolithic limestone. It has a diameter of $40 \mathrm{~cm}$ and a preserved height of $20 \mathrm{~cm}$. The opening's diameter is $20 \mathrm{~cm}$ and its depth is $17 \mathrm{~cm}$. The excavators have suggested that this object was used as a mortar. ${ }^{67}$

Partly preserved NP SO 25 is a column base, which has been transformed into a shallow basin (Fig. 13c). The basin has an irregular rim (trapezoid in section). In one of the corners there is a narrow notch. The surface is rather rough. Holes are visible on the lower side of the column base. The rock type cannot be unequivocally determined. The vessel has

\footnotetext{
67 Daszewski 1970: 127.
} 
a length of $34 \mathrm{~cm}$, width of $22 \mathrm{~cm}, 2 \mathrm{~cm}$ depth, and a preserved height of $14 \mathrm{~cm}$. Perhaps similarly to NP SO 16 it was used for soaking or rinsing.

\section{MISCELLANEOUS}

NP SO 42 is a cylindrical and hollow stone object, broken on one side (Fig. 14). It was found in the House of Aion. The bottom part is either missing or is buried in the ground; this could not be unequivocally verified. The entire inner surface is covered with white lime/plaster. The outer surface is rough, porous. The object is made of calcarenite. Its diameter is $59 \mathrm{~cm}$ and a preserved height $-45 \mathrm{~cm}$. It could have been a storage vessel with the plaster as an impregnating material.

\section{CONCLUSIONS}

The above presented analysis of stone implements combined with the results of studies on pottery from the site ${ }^{68}$ allows a probable reconstruction of some of the activities that the last inhabitants of Villa of Theseus, and to a lesser extent the House of Anion, were engaged in. These were mainly connected with food processing, breeding animals and small-scale industrial output. ${ }^{69}$ The community organised their working areas according to the labour specification: the western areas (six small enclosures) as well as some rooms in the south-west corner $^{70}$ of the building were used for husbandry, and the southern rooms of Villa of Theseus functioned as food (or other material) processing and storage facilities (the squatters' workshop and various storage vessels e.g. NP SO 02, NP SO 20, NP SO 16). In the southern part of the villa (rooms 44, 44a), the squatters had built two lime kilns. The evidence from the House of Aion points out to a different activity, possibly olive oil production.

It is not yet certain how and whether squatters used the more advanced installations e.g. the Pompeian mill or the lever and screw weight.

\section{Acknowledgments}

I would like to thank Professor Wiktor Daszewski and Dr Henryk Meyza for allowing me to study the material from Nea Paphos. Special thanks to Dr Meyza for providing me with the necessary documentation and unpublished field reports. Additionally, I would like to thank Dr Hubert Kiersnowski for his suggestions regarding the rock type identification.

68 Daszewski 1970: 124, 127-128.

${ }^{69}$ Preliminary results of studies on stone implements from Paphos Agora Project suggest rudimentary function for these objects, related to food processing and the production of liquids, herbs and cosmetics; see: Florek 2016.

70 Daszewski 1970: 124. 


\section{References}

Atalar, C., Kilic, R. 2006: Geotechnical properties of Cyprus clays, [in:] Culshaw, M.G., Reeves, H.J., Jefferson, I., Spink, T.W. (Eds), Engineering Geology for Tomorrow's Cities. The 10th IAEG Congress, Nottingham, 1-8

Blitzer, H. 1995: Minoan Implements and Industries, [in:] Shaw, J.W. et al., Kommos: An Excavation on the South Coast of Crete I. The Kommos Region and Houses of the Minoan Town I. The Kommos Region, Ecology and the Minoan Industries, Princeton, 403-536

Chavane, M.-J. 1975: Salamine de Chypre VI. Les petits objets, Paris

Daszewski, W.A. 1970: Polish Excavations in Kato (Nea) Paphos: Second Preliminary Report: Seasons 1968-1969, RDAC 1970, 112-141

Daszewski, W.A 1972: Polish Excavations at Kato Paphos in 1970 and 1971, RDAC 1972, 204-236

Daszewski, W.A. 1999: Nea Paphos Excavations, 1998, PAM X, 163-173

DepAntiquitesCyprus: http://www.mcw.gov.cy/mcw/da/da.nsf/DMLexcavat_en/ DMLexcavat_en?OpenDocument (accessed April, 2016)

Dzwoniarek, M. 2014: Wstępne badania geologiczne w starożytnym Nea Pafos na Cyprze, [in:] Drzymała, J. (Ed.), Interdyscyplinarne zagadnienia w górnictwie i geologii V, Wrocław, 41-47

Florek, M. 2016: Znaleziska kamienne odkryte podczas wykopalisk na Agorze w Nea Paphos/Stone finds uncovered during excavation in the Agora of Nea Paphos, [in:] Papuci-Władyka, E., Dobosz, A. (Eds), W sercu starożytnego miasta. Pięć lat badań krakowski archeologów na agorze w Pafos na Cyprze (2011-2015)/In the heart of the Ancient City. Five years of Krakow archaeologists' research at the Paphos Agora On Cyprus (2011-2015), Kraków, 54-56

Frankel, R. 1999: Wine and Oil Production in Antiquity in Israel and Other Mediterranean Countries, JSOT/ASOR Monograph Series 10, Sheffield

GeolSurveyDep: http://www.moa.gov.cy/moa/gsd/gsd.nsf/dmlSitemap_en/dmlSitemap_ en?OpenDocument (accessed April, 2016)

Gwiazda, M. 2014: Economy of Hellenistic, Roman and Early Byzantine Settlement in Jiyeh (Porphyreon), Lebanon, Archeologia (V) LXII-LXIII, 31-44

Hadjisavvas, S. 1992: Olive oil processing in Cyprus: From the Bronze Age to Byzantine Period, SMA 99, Nicosia

Israel, Y. 2009: A Byzantine Press at Ashkelon, [in:] Ayalon, E., Frankel, R., Kloner, A. (Eds), Oil and Wine Presses in Israel from the Hellenistic, Roman and Byzantine Periods, BAR-IS 1972, Oxford, 355-358

Jacobs, I. 2009: Encroachment in the Eastern Mediterranean from the Fourth to the Seventh Century AD, Ancient Society 39, 203-243

Jacobsen, L.K. 2005: The ground stone industry, [in:] Wriedt Sørensen, L., Winther Jacobsen, K. (Eds), Panayia Ematousa I. A rural site in south-eastern Cyprus, Monographs of the Danish Institute at Athens 6/1, Athens, 403-423 
Lepareux-Couturier, S. 2011: Les meules gallo-romaines du chef lieu de cité des Meldes (Meaux, Seine-et-Marne), première approche, [in:] Buchsenschutz, O., Jaccottey, L., Jodry, F., Blanchard, J.L. (Eds), Évolution typologique et technique des meules du Néolithique à l'an mille sur le territoire français, Actes des $\mathrm{III}^{\mathrm{e}}$ Rencontres Archéologiques de l'Archéosite gaulois, Aquitania Supplément 23, Strasbourg, 409-433

Lepareux-Couturier, S. 2014: Complex dressing patterns on grinding surfaces of rotary querns and millstones from Antiquity, France, AmS Skrifter 24, Stavanger, 149-158

Lewit, T. 2007: Absent-Minded Landlords and Innovating Peasants? The Press in Africa and the Eastern Mediterranean, [in:] Lavan, L., Zanini, E., Sarantis, A. (Eds), Technology in Transition A.D. 300-650, Leiden-Boston, 119-142

Lichocka, B., Meyza, H. 2001: Seismic Events and the Evidence of Coins and Pottery. The Case of Destruction of the House of Aion in Paphos, EtudTrav XIX, 145-208 Mango, M. 2008: Baths, reservoirs and water use at Androna in late antiquity and the early Islamic period, [in:] Bartl, K., Al-Razzaq Moaz, A. (Eds), Residences, Castles, Settlements. Transformation processes from late antiquity to early Islam in Bilad al Sham: proceedings of the international conference held at Damascus, 5-9 November, 2006, Damascus, 73-88

Mead, L., Austin, G.S. 2006: Dimension Stone, [in:] Kogel, J.E., Trivedi, N.C., Barker, J.M., Krukowski, S.T. (Eds), Industrial Minerals and Rocks. Commodities, Markets, Uses, Littleton, 907-924

Moritz, L.A. 1958: Grain mills and flour in Classical Antiquity, Oxford

Peacock, D.P.S. 1989: The mills of Pompeii, Antiquity 63/239, 205-214

Peacock, D. 2013: The Stone of Life. Querns, Mills and Flour, Production in Europe up to c. AD 500, Southampton Monographs in Archaeology New Series 1, Southampton Poupaki, E. 2009: Stone agricultural implements from the island of Kos: The evidence from Kardamaina, the ancient demos of Halasarna, [in:] Deligiannakis, G., Galanakis, Y. (Eds),The Aegean and its Culture. Proceedings of the first Oxford-Athens graduate student workshop organized by the Greek Society and the University of Oxford Taylor Institution, 22-23 April 2005, BAR-IS 1975, Oxford, 109-119

Rautman, M. 2011: Sardis in Late Antiquity, [in:] Dally, O., Ratté, C. (Eds), Archaeology and the Cities of Asia Minor in Late Antiquity, Kelsey Museum Publication 6, Ann Arbor, 1-26

Russell, B.J. 2013: Gazetteer of Stone Quarries in the Roman World, http://www. romaneconomy.ox.ac.uk/databases/stone_quarries_database/(accessed April 2016) Waelkens, M., Vanhaverbeke, H., Martens, F., Talloen, P., Poblome, J., van Thuyne, T., Putzeys, T. 2006: The Late Antique City in Southwest Anatolia. A Case Study. Sagalassos and its Territory, [in:] Krausse, J.-U., Witschel, C. (Eds), Die Stadt in der Spätantike - Niedergang oder Wandel? Aktes des internationalen Kolloquiums in München am 30. und 31. Mai 2003, HistEinz 190, Stuttgart, 199-255

Waliszewski, T. 2014: Elaion. Olive Oil Production in Roman and Byzantine SyriaPalestine, PAM Monograph Series 6, Warszawa 
Williams-Thorpe, O., Thorpe, R.S. 1993: Geochemistry and trade of Eastern Mediterranean millstones from the Neolithic to the Roman periods, JAS 20/3, 263-320

Wright, K. 1992a: Ground Stone Assemblage Variations and Subsistence Strategies in the Levant 22,000 to 5,000 b.p., unpublished $\mathrm{PhD}$ thesis, Yale University, New Haven

Wright, K. 1992b: A classification System for Ground Stone Tools from the Prehistoric Levant, Paléorient 18/2, 53-81 


\section{ÉTUDES et TRAVAUX XXXI / 2018}

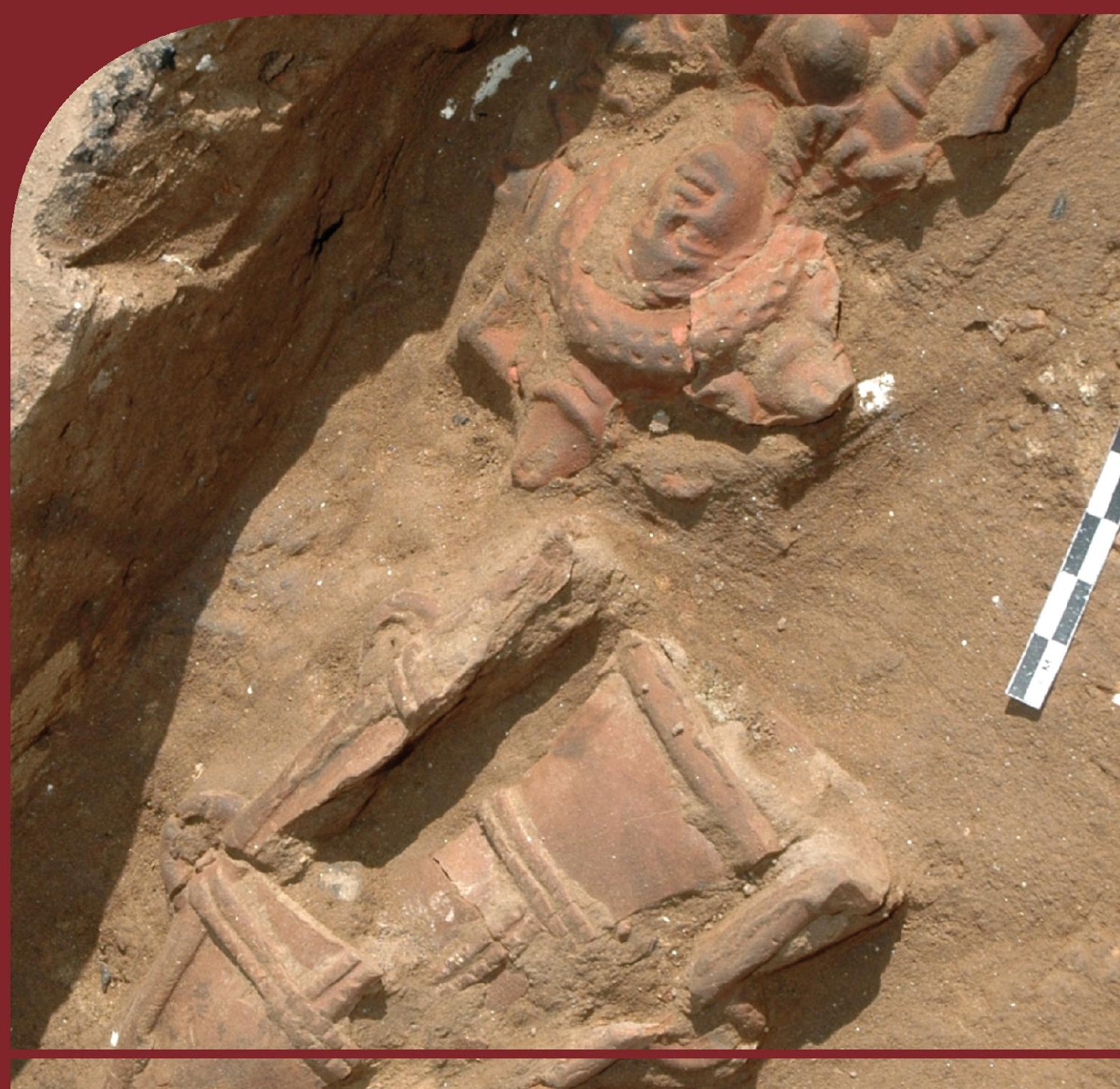

Institut des Cultures iyréditerranéennes et Oilentales FORIKSiO - de PAcadémie Polonaise des Sciences DS PA 


\section{COMITÉ DE RÉDACTION SCIENTIFIQUE}

Maciej Makowski - rédacteur en chef

Jadwiga Iwaszczuk - rédacteur

Mariusz Drzewiecki - sécretaire de la rédaction

Karol Myśliwiec - rédacteur thématique du volume

CONSEIL SCIENTIFIQUE DU JOURNAL

M. Kobusiewicz (IAE PAS, Warszawa), E. Laskowska-Kusztal (IMOC PAS, Warszawa)

D. Michaelides (University of Cyprus, Nicosia)

J.Ch. Moretti (IRAA-MOM, Université de Lyon 2/CNRS)

D. Raue (Ägyptisches Museum der Universität Leipzig), P. Reynolds (ICREA, España)

D. Welsby (British Museum, London)

\section{COMITÉ SCIENTIFIQUE DE LECTURE}

H.D. Baker (University of Toronto), P. Ballet (ArScAn-ESPRI, Université Paris Nanterre),

N. Beaux Grimal (IFAO, Cair/Collège de France, Paris), A. Dodson (University of Bristol),

L. Gabolde (CNRS), C. Gobeil (Egypt Exploration Society, London),

J. Holaubek (Institut für Ägyptologie, Wien), S. Ikram (American University in Cairo),

K. Innemée (Universiteit Leiden), Ch. Leitz (Universität Tübingen),

A. Loprieno-Gnirs (Universität Basel), Ch.E. Loeben (Museen für Kulturgeschichte, Hannover),

S. Ortisi (Universität München), A. Peignard-Giros (HiSoMA-MOM, Université de Lyon 2/CNRS),

E. Rova (Università Ca' Foscari Venezia), A. Sasson (San Diego Natural History Museum),

G. Schreiber (Eötvös Loránd University, Budapest), E. Teeter (University of Chicago),

Y. Tristant (Macquarie University, Sydney), V. Vaelske (independent researcher),

V.W.J. van Gerven Oei (independent researcher), H. Vymazalová (Charles University, Prague),

K. Winther-Jacobsen (Danish Institute at Athens),

J.A. Ostrowski, E. Papuci-Władyka, J. Śliwa (IA JU, Kraków),

R. Czerner (WUST, Wrocław), A. Ćwiek (IA AMU, Poznań),

K. Domżalski (IAE PAS, Warszawa), M. Pinker (FOS UW, Warszawa),

Ł. Niesiołowski-Spanò (IH UW, Warszawa), M. Gawlikowski (PCMA UW, Warszawa), K.O. Kuraszkiewicz (DE FOS UW, Warszawa), M. Barwik, P. Dyczek, W. Godlewski,

S. Rzepka, J. Żelazowski, A. Niwiński (IA UW, Warszawa)

\section{RÉDACTION TECHNIQUE}

Maciej Makowski, Jadwiga Iwaszczuk

CORRECTION LINGUISTIQUE

Jo Harper 
ÉTUDES et TRAVAUX

XXXI 
INSTYTUT KULTUR ŚRÓDZIEMNOMORSKICH I ORIENTALNYCH POLSKIEJ AKADEMII NAUK

\title{
STUDIA i PRACE
}

XXXI

\author{
gO IKŚiO \\ ESA PAN \\ WARSZAWA \\ 2018
}


INSTITUT DES CULTURES MÉDITERRANÉENNES ET ORIENTALES DE L'ACADÉMIE POLONAISE DES SCIENCES

\section{ÉTUDES et TRAVAUX}

XXXI

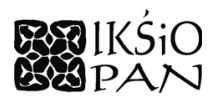

VARSOVIE

2018 
Publication scientifique financée dans le cadre du programme du Ministre de la Science et de l'Éducation Supérieure « Programme National de Développement de l'Humanistique » pour les années 2016-2021 (projet $n^{\circ} 3 \mathrm{bH} 15009983$ )

\title{
Harodowy PROGRAM ROZWOJU HUMANISTYKI
}

\author{
Copyright $($ ) \\ Instytut Kultur Śródziemnomorskich i Orientalnych PAN \\ et les Auteurs \\ Warszawa 2018
}

ISSN 2084-6762

(avant $2011: 0079-3566$ )

e-ISSN 2449-9579

Version première en papier, imprimée en Pologne - 150 copies

Version électronique accessible sur http://www.etudesettravaux.iksiopan.pl

Édition: Polskie Towarzystwo Historyczne et Wydawnictwo Neriton, Warszawa

Conception générale de couverture : J. Iwaszczuk Photo de couverture : P. Moser (C) Schweizerisches Institut für Ägyptische Bauforschung und Altertumskunde in Kairo

(terre cuites d'Aswan/Syene) 


\section{Table des matières}

KAROL MYŚLIWIEC

$(E T=E t u d T r a v / 50) \times 30$

HASSAN Aglan

Hatshepsut and the Apis Race: New Quartzite Relief Fragments

from Dra' Abu el-Naga

Amgad Joseph

Divine Wrath in Ancient Egypt

Amgad Joseph

Pain Infliction, Inflictors and Healers in Egyptian Religious, Magical

and Literary Perceptions

MirosŁaW BarwiK

New Dipinti in the Birth Portico of the Hatshepsut Temple at Deir el-Bahari

KrzyszTOF BorysŁaWsKi, ANNA NiwiŃSKA, ANDRZEJ NiwiŃSKI,

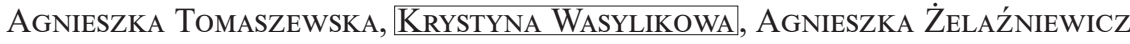

A Bulb of Narcissus on the Egyptian Mummy from University

of Wrocław Collection

LINDA CHAPON

Some Reliefs Representing the King in the Heb Sed Robe Discovered in the Henket-Ankh

Philippe Guillaume

Debunking the Latest Scenario on the Rise of the Pork Taboo

Mariola Hepa

A Clay Gladius Scabbard from Area 13c in the Ancient Roman Town of Syene

Emanuele E. Intagliata

Pinpointing Unrest at Palmyra in Early Islamic Period. The Evidence from Coin Hoards and Written Sources 
KATARZYNA KAPIEC

The Sacred Scents: Examining the Connection Between the ' $n t j w$ and $s f \underline{t}$ in the Context of the Early Eighteenth Dynasty Temples

DOMINIKA MAJCHRZAK

Remarks on the Iconographic Motif of the Birdman in Mesopotamian Glyptic Art of the Third Millennium BC

KAROLINA PAWLIK

Stone Artefacts from Late Roman Occupation Phases in Nea Paphos

ABRÉVIATIONS 
THE VOLUME IS PUBLISHED TO CELEBRATE

THE $50^{\text {TH }}$ ANNIVERSARY

OF THE

ÉTUDES ET TRAVAUX

ESTABLISHED IN 1966 